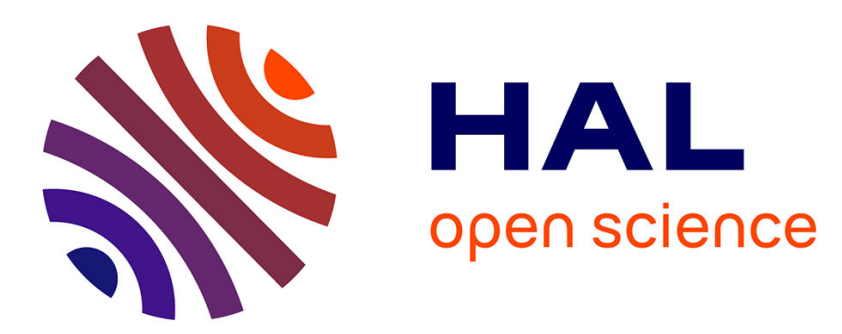

\title{
Energy valorization of industrial biomass: Using a batch frying process for sewage sludge
}

M.H. Romdhana, Anwar Hamasaiid, Bruno Ladevie, Didier Lecomte

\section{To cite this version:}

M.H. Romdhana, Anwar Hamasaiid, Bruno Ladevie, Didier Lecomte. Energy valorization of industrial biomass: Using a batch frying process for sewage sludge. Bioresource Technology, 2009, 100 (15), pp.3740 - 3744. 10.1016/j.biortech.2009.01.043 . hal-01651372

\section{HAL Id: hal-01651372 https://imt-mines-albi.hal.science/hal-01651372}

Submitted on 7 Nov 2019

HAL is a multi-disciplinary open access archive for the deposit and dissemination of scientific research documents, whether they are published or not. The documents may come from teaching and research institutions in France or abroad, or from public or private research centers.
L'archive ouverte pluridisciplinaire HAL, est destinée au dépôt et à la diffusion de documents scientifiques de niveau recherche, publiés ou non, émanant des établissements d'enseignement et de recherche français ou étrangers, des laboratoires publics ou privés. 


\title{
Energy valorization of industrial biomass: Using a batch frying process for sewage sludge
}

\author{
M.H. Romdhana, A. Hamasaiid, B. Ladevie, D. Lecomte* \\ Université de Toulouse, Mines Albi, RAPSODEE UMR CNRS 2392, F 81013 Albi, France
}

\begin{abstract}
A B S T R A C T
This paper studies the energy valorization of sewage sludge using a batch fry-drying process. Drying processes was carried out by emerging the cylindrical samples of the sewage sludge in the preheated recycled cooking oil. Experimental frying curves for different conditions were determined. Calorific values for the fried sewage sludge were hence determined to be around $24 \mathrm{MJ} \mathrm{kg}^{-1}$, showing the auto-combustion potential of the fried sludge. A one-dimensional model allowing for the prediction of the water removal during frying was developed. Another water replacement model for oil intake in the fried sewage sludge was also developed. Typical frying curves were obtained and validated against the experimental data.
\end{abstract}

Keywords:

Sewage sludge

Frying

Thermal drying

Biomass

\section{Introduction}

Sewage sludge is formed during wastewater treatment plant (WWTP) operations. The production of sludge available for disposal depends therefore on the financial, environmental and technological limitation of the given city or country (Werther and Ogada, 1999). In Europe, several pieces of legislation such as The Urban Waste Water Directive 91/271/EEC (Council Directive, 1991) impose a series of secondary treatment of wastewater in order to improve the aqueous environment. Indeed, the production of sludge has not stopped increasing. The amount generated annually is around 6900 million dry tons in the European Union (Catallo and Comeaux, 2008). Sludge may contain a high concentration of organic pollutant and toxic metal (EPA, 1979). It is disposed of for safety and environmental reasons or is recycled. However, recycling and reuse of sludge present a serious challenge because of its heterogeneous nature. The nutriment content of nitrogen and phosphor has fertilizing properties, however, heavy metals can be harmful when assimilated into the human food chain (Fytili and Zabaniotou, 2008). Although, landfilling presents the major alternative in developed countries with approximately $40 \%$ in the European Union (Fytili and Zabaniotou, 2008; Werther and Ogada, 1999), this solution induces many uncertainness. One of the problems of landfilling is the unsteady physical and chemical nature of sludge, namely odors, gas emissions $\left(\mathrm{CH}_{4}\right)$ and leachate transport into neighboring subsoils. Some legislation proposes to establish typical standards for

\footnotetext{
* Corresponding author. Tel.: +33 5634932 50; fax: +33 563493243 . E-mail address: lecomte@enstimac.fr (D. Lecomte).
}

sludge in order to reduce the risks and to ensure protection of the ground water. In coastal areas, transport by boats and dumping in the deep sea are actions taken by some countries. Nevertheless, these activities are unsafe, as the seas cannot absorb unlimited quantities of waste (Fresenius, 1990). In addition, there is a risk of contamination of the maritime coast as sludge contains great quantities of pathogenic matter (Eljarrat et al., 2001).

It has been reported that thermal oxidation processes result in the best global warming balance from an energy perspective (Houillon and Jolliet, 2005). These processes involve thermal destruction of toxic organic compounds and provide a large volume reduction of about 30\% after incineration (Malerius and Werther, 2003). The energy balance for a sludge combustion process can only be positive when the required energy for drying is less than the calorific value of the sludge.

In fact, incineration of sewage sludge requires additional energy during the thermal drying step as it contains a large volume of water (60-80\%) (Werther and Ogada, 1999).

According to Furness et al. (2000), the solid content in the sludge should be considerably reinforced to be auto-thermal. For this, direct or indirect drying methods are often used nowadays. Afterwards, coal, oil, gas or dried sludge may be used (Tchobanoglous et al., 2003) to fuel the incineration process. The present work deals with an innovative technique for the thermal drying and conditioning of sludge by a fry-drying process. This process offers the possibility of valorization of two wastes: sewage sludge and recycled cooking oil combined into a solid fuel. 


\section{The fry-drying concept}

Frying, one of the oldest processes of the food industry consists of drying by contact with hot oil and involves simultaneous heat and mass transfer (Moreira et al., 1999). Knowledge of the heat and mass transfer rates during the frying process is essential in order to evaluate the quality of the final product such as calorific values, oil uptake, porosity changes, etc. While the frying of food products has been the subject of a large number of investigations (Baumann and Escher, 1995; Pedreschi and Moyano, 2005; Chen and Moreira, 1997; Ngadi et al., 1996; Totte et al., 1996), the literature concerning the frying of sewage sludge is scarce. Silva et al. (2005) used a commercial fryer with a capacity of 51 using fresh and used oil. They introduced the cylindrical samples of sludge (20-26 mm diameter and $40 \mathrm{~mm}$ length) into the oil heated to $190{ }^{\circ} \mathrm{C}$ and $215^{\circ} \mathrm{C}$. Their methods resulted in a dried sludge with less than $5 \%$ moisture and $24 \mathrm{MJ} / \mathrm{kg}$ calorific value after $600 \mathrm{~s}$ of frying. Peregrina et al. (2006a, b) examined fry drying of municipal sewage sludge using recycled cooking oil. The experimental tests were carried out using a continuous method with on-line weight measuring at operating temperatures between 120 and $180^{\circ} \mathrm{C}$. These studies indicated that oil acts as a medium of heating and as a component of the final product that improves its calorific value.

The above studies provided important information about the physical mechanism that takes place in the fry drying of sewage sludge. However, moisture and oil transfer are still not understood. The simultaneous aspect of the thermal and mass transfer, and the change of the physical properties of the product with the temperature and moisture, makes the theoretical treatment more complicated. Several mathematical models were developed for frying of food material. The basic energy and mass equations are often the same. The difference between the models lies in the choice of the transport mechanisms, the reformulation of the medium, the boundary conditions and the physical properties. Farkas et al. (1996a, b) proposed a one-dimensional model, involving two regions in the fried material: the crust and core. The crust region was defined by two criteria: its temperature is higher than the boiling point and the concentration of liquid water is negligible. Heat is transmitted by conduction. Additionally, one component of the energy leaves the heart by advection. Each region is in a dynamic state during frying, the crust is becoming thicker and the core thickness is decreasing.

Yamsaengsung and Moreira (2002) used a multiphase porous media model. They considered six phases (liquid water, bound water, vapor, air, oil and solid matrix). The transport of the liquid phases (water and oil) was supposed to be controlled by two phenomena: (1) capillarity which depends on saturation of each phase and the temperature and (2) convection. Gas phase transport, was reported to be a result of convective flow and molecular diffusion. In each phase, convection was expressed by Darcy's law. Baik and Mittal (2005) developed a non-symmetric model without considering crust formation. The moisture was assumed to diffuse through the product by a gradient of concentration and boiling on the surface.

Fassano and Mancini (2007) presented a mathematical model for deep frying using a one-dimensional geometry assumption involving an inner zone saturated with liquid water followed by a region of pure vapor. The transport of the liquid was assumed to happen by diffusion with a constant diffusivity and by the pressure gradient in the vapor phase. In order to improve their approach, Fassano and Mancini (2008) reformulated their model by replacing the diffusive transport of liquid water by a Darcy's law including the effect of capillarity, and vapor permeability as a function of temperature.

\section{Present model}

\subsection{The problem description and assumptions}

The aim of this work is to study the main phenomena occurring during a fry-drying process. Two quantities change greatly during frying: moisture content indicating the water loss from the sewage sludge and oil content indicating the amount of oil that the sample uptakes during frying.

Cylindrical samples prepared from a modified syringe are placed in an oil heat bath. There is, however, a certain transfer of heat coupled to the mass transfer of the water and the oil. Heat is transferred from the surrounding oil to the product surface by convection and through the product by conduction. We assume that moisture inside the sludge diffuses to its surface due to concentration gradient then leaves the surface in the form of vapor at atmospheric pressure. Oil diffuses in the direction opposite to that of water. In addition, the following assumptions were made: (a) The sludge is initially considered isotropic and homogeneous. (b) The initial moisture is uniform. (c) Since the radial dimensions are much smaller than those along the axial length, an infinite cylinder model was assumed. (d) Moisture diffusion coefficient was assumed to be constant during frying but a function of the oil temperature and initial moisture. (e) The mass diffusion of oil in the fried material has a negligible effect on other mass fluxes (i.e. the rate of water removal).

\subsection{Governing equation}

The mathematical formulation may be simplified by considering axial symmetry of the sample. The governing differential equations describing moisture diffusion in the product during frying consider diffusion in the form of a Fick's law

$\frac{\partial M}{\partial t}=\frac{\partial}{\partial r}\left(D_{w} \frac{\partial M}{\partial r}\right)$

where $M[\% \mathrm{~kg}$ water by $\mathrm{kg}$ fried product $]$ is the local moisture content, $D_{w}\left[\mathrm{~m}^{2} \mathrm{~s}^{-1}\right]$ is the moisture diffusion coefficient, $t[\mathrm{~s}]$ is the frying time, and $r[\mathrm{~m}]$ is the radius of cylindrical particle.

The relationship between the diffusion coefficient constant, oil temperature and initial moisture content was assumed in the form:

$D_{w}=\left(a T_{\infty}+b\right) \exp \left(\frac{-\left(c T_{\infty}+d\right)}{T_{\infty}}+e\left\langle M_{0}\right\rangle\right)$

where $a, b, c, d$ and $e$ are the correlation factors, $T_{\infty}[k]$ is the surrounding oil temperature, the operator $\langle\cdots\rangle$ denotes the volume average of the moisture content, and the subscript 0 denotes the initial value.

The mass transfer boundary condition for moisture is (Farkas et al., 1996a; Chen and Moreira, 1997):

$\left.\frac{\partial M}{\partial r}\right|_{r=0}=0$

At the surface of the product, moisture is in instantaneous equilibrium with oil (Ateba and Mittal, 1994). The boundary condition takes the form:

$M(R, t)=\left\langle M_{e q}\right\rangle$

where $R[\mathrm{~m}]$ is the half thickness of the particle and the subscript eq denotes the equilibrium.

$\left\langle M_{e q}\right\rangle$ is the equilibrium moisture content determined from long term experiments and from calculation. Moreover, during calculation this parameter still not known until the end. Therefore, the experimental equilibrium moisture content is attributed to the 
moisture content at the surface of the product as boundary condition.

The initial condition is the following:

$M(r, 0)=\left\langle M_{0}\right\rangle$

The above governing equations were solved by using finite difference method with implicit scheme. Average moisture content (6) was calculated by numerical integration of the local concentration at each time step using a Simpson's rule

$\langle M\rangle=\frac{1}{v} \int_{v} M d v$

The moisture content of fried sludge was defined as the quantity of water per unit mass of wet product as follows:

$M=\frac{m_{w}}{m_{w}+m_{s}+m_{0}}$

where $m[\mathrm{~kg}]$ is the mass of considered phase, and subscripts $w, s$ and $o$ denote water, solid and oil, respectively.

The oil uptake of fried sludge was defined as the quantity of oil per unit mass of wet product:

$O=\frac{m_{o}}{m_{w}+m_{s}+m_{o}}$

Up to now, no physical model has been proposed in the literature to predict the oil uptake during frying without resolving the differential equation of oil transport. Although, several main possible phenomena were proposed, namely, the cooling phase effect in partially fried food material (Ufheil and Escher, 1996; Chen and Moreira, 1997) occurs when the product is removed from the fryer, water substitution (Rice and Gamble, 1989) and surface-active agent activity resulting from the reduction of the interfacial tension between the oil and the product (Dana and Saguy, 2006). In order to develop an oil uptake model, the water replacement possibility was considered. The mechanism describes oil uptake instantly through void left by water after evaporation. Therefore, a mass balance on the product during frying gives:

$O=\frac{\rho_{o}}{\rho_{w}}\left(M_{0}-M\right)$

where $\rho\left[\mathrm{kg} \mathrm{m}^{-3}\right]$ is density.

The following linear correlation was used to describe the density of recycled cooking oil (Peregrina, 2005):

$\rho_{o}=934.34-0.637 T_{\infty}\left[{ }^{\circ} \mathrm{C}\right]$

\section{Method}

The sewage sludge used in the experiments was produced by TEMBEC SA Company (Saint-Gaudens, France), manufacturing of pulp paper. The frying oil was provided by the Sud Recuperation Company (France). It is primarily a used oil collected from restaurant and food industry.

The experiments were carried out in an electric powered fryer with a capacity of 51 of oil and electrical resistance of $2 \mathrm{~kW}$ submerged at the bottom of the tank. The oil temperature was kept at the required temperature by a PID controller.

One impeller driven by an adjustable speed motor was added to the device. A light speed stirrer was adjusted to create a more homogenous oil temperature throughout the tank.

In order to have geometric uniformity, the sludge was modeled using syringes with the edge cut off. Sludge cylindrical samples were prepared with length of $32 \mathrm{~mm}$ and different diameters (4.4, 8 and $12 \mathrm{~mm}$ ). The length is limited to $32 \mathrm{~mm}$ to avoid damaging the sample during frying and especially when its pull out from the fryer for analyzes. The moisture content was determined by weight loss ( $0.1 \mathrm{mg}$ precision) after drying the sample $24 \mathrm{~h}$ at $103-105^{\circ} \mathrm{C}$ in a forced air oven. Using the mass balance of the product, oil contents at different frying times were determined. Then the fried sludge was analyzed for lower heating value using a self-integrated and microprocessor controlled chromatographic elemental analyzer (model: NA 2100 Protein, CE Instruments, Italy).

\section{Result and discussion}

The estimation of the above five parameters ( $a, b, c, d$ and $e$ ) was carried out using an inverse analysis method, for moisture loss during frying of sludge. The method is based on the minimization of the residual sum of squares $O b$.

$O b=\sum_{i=1}^{n_{1}} \sum_{j=1}^{n_{2}}\left(\operatorname{Exp}_{i, j}-C a l_{j}\right)^{2}$

where $n_{1}$ is the number of replicate and other experiments conditions, $n_{2}$ is the number of experimental values, Exp is the experimental value, and $\mathrm{Cal}$ is the calculated value.

Moisture diffusion coefficient increases as the initial moisture content and oil temperature during frying:

$D_{w}=\left(0.0013 T_{\infty}+1.02\right) \times 10^{-6} \exp \left(\frac{13 T_{\infty}-3825}{T_{\infty}}+0.0107\left\langle M_{0}\right\rangle\right)$

Fig. 1 shows experimental results and model predictions of water loss during frying. The drying rate is strongly accelerated with oil temperature ranging between 110 and $140{ }^{\circ} \mathrm{C}$. It takes about $40 \mathrm{~min}$ for the product to reach a final moisture content of about $4 \%$ when fried at $110^{\circ} \mathrm{C}$ in comparison with only $10 \mathrm{~min}$ when sludge is frying at $140^{\circ} \mathrm{C}$. Differences in drying time would be more pronounced during industrial operations with a larger range of oil temperatures in a continuous fryer (Baumann and Escher, 1995). The calculated values of moisture diffusivity coefficient range from 4.7931 to $20.479 \times 10^{-9} \mathrm{~m}^{2} \mathrm{~s}^{-1}$. These values are higher than $0.82-1.19 \times 10^{-9} \mathrm{~m}^{2} \mathrm{~s}^{-1}$ in deep-fat tofu frying at $147-172{ }^{\circ} \mathrm{C}$ (Baik and Mittal, 2005), and potato chips frying (Pedreshi et al., 2007) at $120-180^{\circ} \mathrm{C}\left(4.93-14.7 \times 10^{-9} \mathrm{~m}^{2} \mathrm{~s}^{-1}\right)$, however similar to those reported by Sosa-Morales et al. (2006) for frying of pork meat at $90-110^{\circ} \mathrm{C}\left(1.59-30.20 \times 10^{-9} \mathrm{~m}^{2} \mathrm{~s}^{-1}\right)$. Then, the differences may be attributed to the nature of the product composition and particularly to microstructure changes (Peregrina et al., 2006a, b) during frying of sludge leading to the formation of large cracks that enable easy water diffusion.

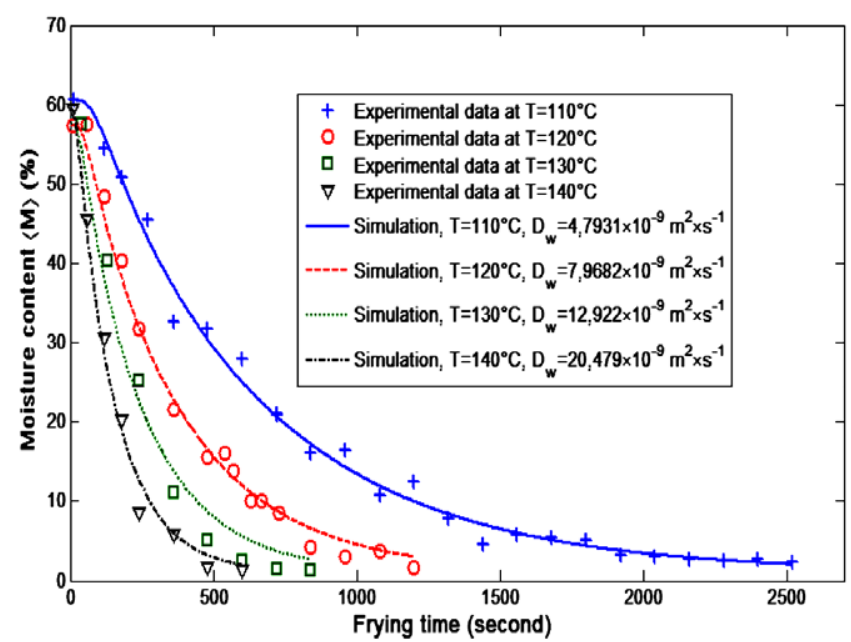

Fig. 1. Drying behavior of sludge cylinder ( $8 \mathrm{~mm}$ thickness) with oil temperature. 
Experimental and simulated water loss for different sludge thicknesses are plotted in Fig. 2. Moisture removal is slower for the sludge with 12 and $8 \mathrm{~mm}$ thickness, with more than $2000 \mathrm{~s}$ required to reach the equilibrium moisture content (4\%). Less than $1000 \mathrm{~s}$ for thin sludge, which is half the time of that of $8 \mathrm{~mm}$. A similar phenomenon was observed in potato chips frying (Moreira et al., 1999), where decreasing the diameter from 1.6 to $0.8 \mathrm{~mm}$ made it possible to reduce frying time in half (180-90 s). This explains the faster drying rate with the smaller sample diameter in which mass transfer area for the mass transfer flux is reduced.

Fig. 3 shows oil uptake as function of oil temperature and frying time. In the early stage of frying the higher oil temperature results in higher oil content. The difference is much greater between 110 and $120^{\circ} \mathrm{C}$ than 130 and $140{ }^{\circ} \mathrm{C}$. Indeed, higher oil temperature ensures the conditions of oil absorption in the beginning of the operation in which drying is critical (Fig. 1), favoring significant evaporation and crust formation with large pore space starting from surface. At the end of frying time the absorption is temperature independent and remains constant at the equilibrium value (45\%). These results are coincident with those found by Pedreshi et al. (2007) for fried potato slices.

Furthermore, we plotted the oil-uptake data as a function of the moisture content in the fried product. Fig. 4 clearly shows that the oil-uptake quantity is related directly to the moisture content after frying which confirms that oil content in the fired sludge is proportional to the amount of water removed during frying. The small scatter between the points observed in Fig. 4 is related to the oil temperature variation. The moisture content goes to $60 \%$ but the oil uptake goes to $50 \%$. This is may be explained essentially by the difference in density between oil and water. Certainly, there are others effects, such as the counter diffusion of the rate of water removal, porosity change, interconnectedness of the pores, and also pressure gradient due for example to the condensation of the steam in the product pores, which produces vacuum.

Fig. 5 presents the reduction of oil content vs. the increasing of sludge thickness. The amount of oil as a percentage of the total fried sludge decreased from $46 \%$ at $4 \mathrm{~mm}$ to $40 \%$ at $12 \mathrm{~mm}$ thickness. Baumann and Escher (1995) observed the same phenomenon with fried potato slices, increasing the thickness of the potato slices from 0.8 to $1.6 \mathrm{~mm}$ reduces the percentage of oil in the chip from $57 \%$ to $46.7 \%$. This may be explained by the relation between the total volume of oil taken up and the available thickness of the samples, i.e. as the smaller diameter cylindrical sludge have a larger surface/volume ratio $\frac{2}{R}$, the volume of oil absorbed increased. Although a shorter drying time, oil diffuses into void left by the water vaporizing independently on the frying time.

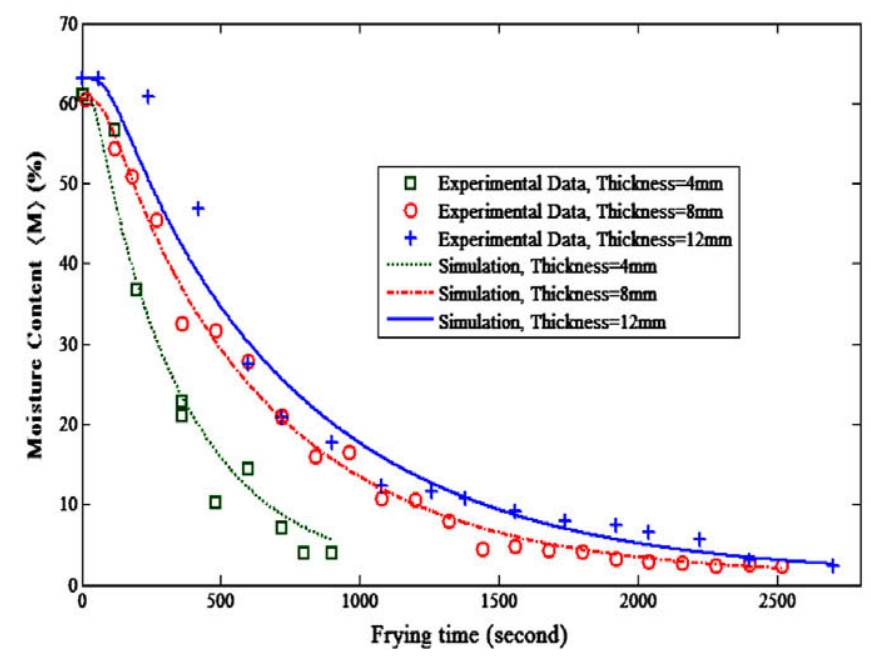

Fig. 2. Effect of sludge thickness on moisture loss during frying.

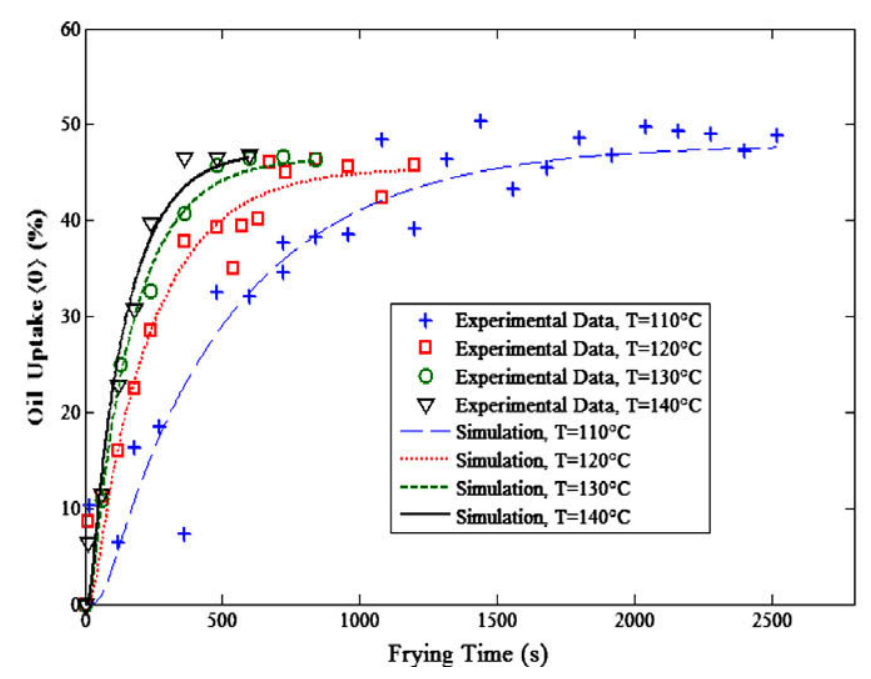

Fig. 3. Predicted and experimental result of sludge's average oil uptake during frying with oil temperature.

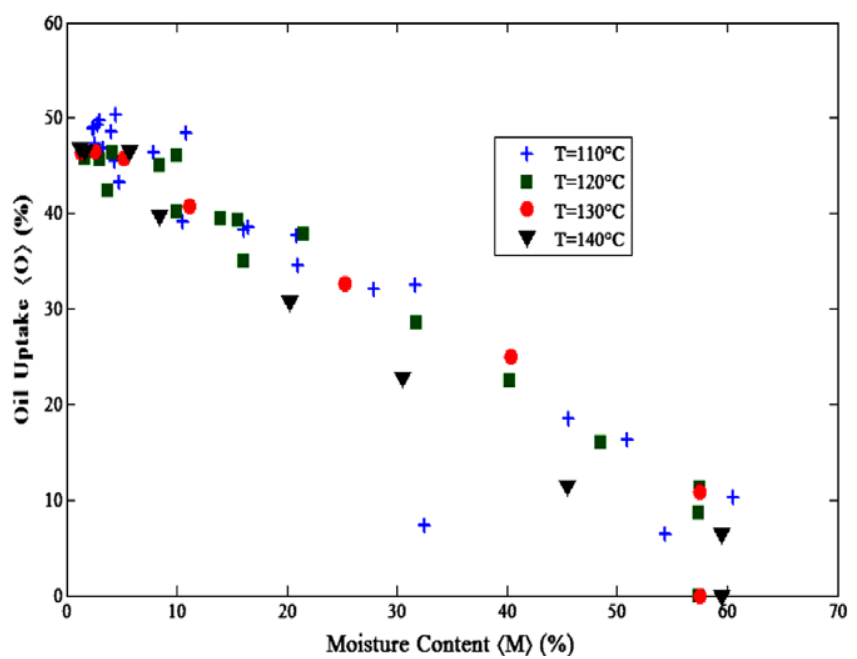

Fig. 4. Relationship between moisture content and oil uptake of fried sludge at different temperatures.

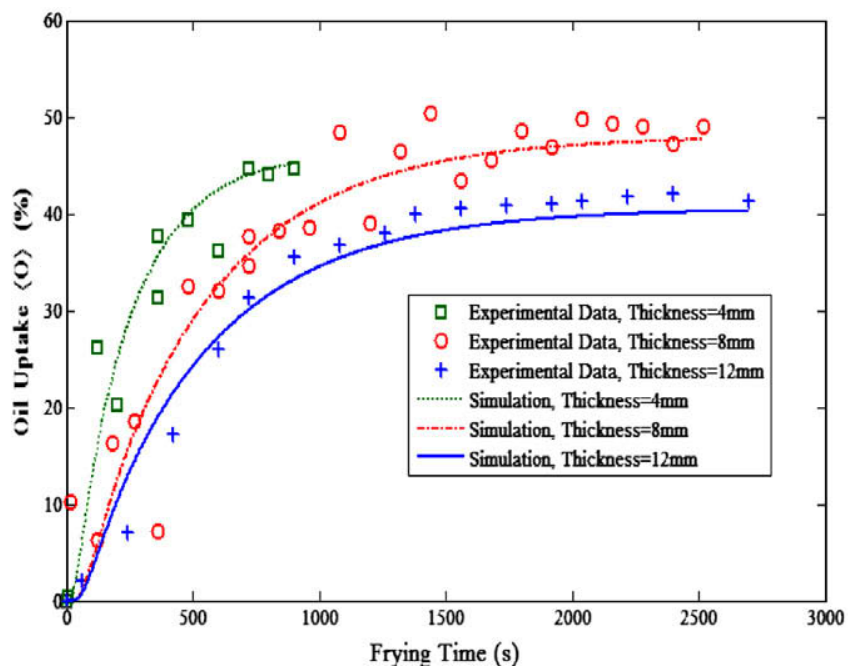

Fig. 5. The effect of sludge thickness on oil uptake. 


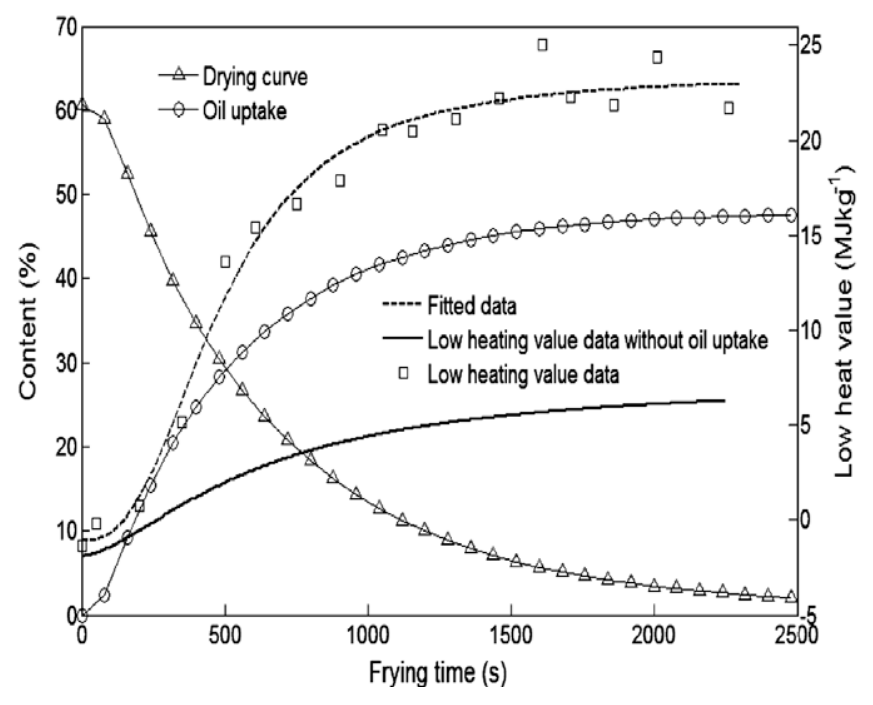

Fig. 6. Lower heating value of fried sludge during the process time.

The difference between 4 and $8 \mathrm{~mm}$ shows a clear difference in oil uptake during the process, but at the end of frying no difference is observed. This disagrees with assumption presented previously. In fact, the thinner samples reach a higher temperature more quickly, at which the oil viscosity decreases making the oil more easily to drip in the product pores.

In order to have a homogeneous analysis at lower heating values, all samples were fried under the same conditions of temperature $\left(110^{\circ} \mathrm{C}\right)$, thickness $(12 \mathrm{~mm})$ and initial moisture content (63\%), but during different frying times. The values of the lower heating of sewage sludge during the process are shown in Fig. 6. During frying, the product was enhanced with oil taking the place of the free porosity. The calorific value rises from $6 \mathrm{MJ} \mathrm{kg}^{-1}$ to $24 \mathrm{MJ} \mathrm{kg}^{-1}$. It is due to the presence of oil in the particle and therefore the heating value of oil, and because of water removal, therefore no energy is needed to convert from liquid to steam. The problem of the sludge combustion plants is the reduced net energy released during the process because of the high energy of the evaporation of the moisture in the sludge and supplementary energy required to maintain auto-thermal combustion. For wet sludge additional fuel is required to maintain a temperature of $850{ }^{\circ} \mathrm{C}$ in the fluidized bed with heating value of $15 \mathrm{MJ} \mathrm{kg}^{-1}$ (Werther and Ogada, 1999). At this point, sludge after around 10 min frying time provides the same result. This shows the effect of the oil impregnation into the sludge and the growing interest to use the fry dried sludge in mono-incineration, wet oxidation or pyrolysis.

\section{Conclusion}

Both mass transfer phenomena that take place during frying of sewage sludge were described: moisture loss and oil uptake. Two kinds of models were used to describe oil uptake and water loss. It was assumed that the oil diffuses into the porosity structures that have been produced by the vaporization of water during frying. It was found that the models were able to predict moisture content and oil uptake in close agreement with experimentally determined data. Oil uptake improves the heat value of fry drying product making sludge more valuable for energy recovery by a combustion process.

\section{Acknowledgements}

The authors would like to acknowledge the financial support of ADME "Agency for environment and energy management" and
Midi-Pyrénées region. The authors would also like to thank Mr. Jean-Claude Poussin and Mr. Bernard Auduc for their contributions in performing the experimental investigations.

\section{References}

Ateba, P., Mittal, G.S., 1994. Dynamics of crust formation and kinetics of quality changes during frying of meatballs. J. Food Sci. 59, 1275-1278.

Baik, O.D., Mittal, G.S., 2005. Heat and moisture transfer and shrinkage simulation of deep-fat tofu frying. Food Res. Int. 38, 183-191.

Baumann, B., Escher, F., 1995. Mass and heat transfer during deep-fat frying of potato slices-I. Rate of drying and oil uptake. Lebensm. Wiss. Technol. 28, 395403.

Catallo, W.J., Comeaux, J.L., 2008. Reductive hydrothermal treatment of sewage sludge. Waste Manage. 28 (11), 2213-2219.

Chen, Y., Moreira, R.G., 1997. Modelling of a batch deep-fat frying process for tortilla chips. Inst. Chem. Eng. 75, 181-189.

Council Directive 91/271/EC of 21 May 1991 concerning urban waste-water treatment. Official Journal of the European Communities.

Dana, D., Saguy, I.S., 2006. Review: mechanism of oil uptake during deep-fat frying and the surfactant effect-theory and myth. Adv. Colloid Interface Sci. 128-130, 267-272.

Eljarrat, E., Caixach, J., Rivera, J., 2001. Evaluation of dioxin contamination sewage sludge discharges on coastal sediments from Catalonia Spain. Water Res. 35, 2799-2803.

EPA, 1979. Process Design Manual for Sludge Treatment and Disposal. Chapter 7: Disinfection. US Environmental Protection Agency.

Farkas, B.E., Singh, R.P., Rumsey, T.R., 1996a. Modeling heat and mass transfer in immersion frying. II. Model solution and verification. Int. J. Food Eng. 29, $227-$ 248.

Farkas, B.E., Singh, R.P., Rumsey, T.R., 1996b. Modeling heat and mass transfer in immersion frying. I. model development. J. Food Eng. 29, 211-226.

Fassano, A., Mancini, A., 2007. A mathematical model for a class of frying processes. Comput. Math. Appl. 53, 395-412.

Fassano, A., Mancini, A., 2008. Modelling the frying of a non-deformable specimen by immersion in edible oil. Comput. Math. Appl. 55 (2), 149-151.

Fresenius, W., 1990. Technologie des eaux résiduaires: production, collecte, traitement et analyse des eaux résiduaires, first ed. Springer-Verlag, Paris.

Furness, D.T., Hogget, L.A., Judd, S.J., 2000. Thermochemical treatment of sewage sludge. Water Environ. J. 14 (1), 57-65.

Fytili, D., Zabaniotou, A., 2008. Utilization of sewage sludge in EU application of old and new methods. Renew. Sust. Energ. Rev. 12 (1), 116-140.

Houillon, G., Jolliet, O., 2005. Life cycle assessment of processes for the treatment of wastewater urban sludge: energy and global warming analysis. J. Clean Prod. 13, 287-299.

Malerius, O., Werther, J., 2003. Modelling the adsorption of mercury in the flue gas of sewage sludge incineration. Chem. Eng. J. 96, 197-205.

Moreira, R.G., Castell-Perez, M.E., Barrufet, M.A., 1999. Deep-Fat Frying Fundamental and Application. US Edition. Aspen Publisher, Inc., Maryland.

Ngadi, M.O., Watts, K.B., Correia, L.R., 1996. Finite element method modelling of moisture transfer in chicken drum during deep-fat frying. J. Food Eng. 32, 1120

Pedreschi, F., Moyano, P., 2005. Oil uptake and texture development in fried potato slices. J. Food Eng. 70, 557-563.

Pedreshi, F., Moyano, F., Suntis, N., Pedreshi, R., 2007. Physical properties of pretreated potato chips. J. Food Eng. 79, 1474-1482.

Peregrina, C.A., 2005. Traitement de boues par friture: des mécanismes physiques à l'éco-conception d'un procédé [En ligne]. Thèse: Institut National des Sciences Appliquées de Lyon, $184 \mathrm{p}$.

Peregrina, C., Arlabosse, P., Lecomte, D., Rudolph, V., 2006a. Heat and mass transfer during fry-drying of sewage sludge. Dry. Technol. 24, 797-818.

Peregrina, C., Arlabosse, P., Lecomte, D., Rudolph, V., 2006b. Life cycle assessment (LCA) applied to the design of an innovative drying process for sewage sludge. Process safety and environment protection. Dry. Technol. 84, 270279.

Rice, P., Gamble, M.H., 1989. Modelling moisture loss during potato slice frying. Int. J. Food Sci. Technol. 24, 183-187.

Silva, D.P., Rudolph, V., Taranto, O.P., 2005. The drying of sewage sludge by immersion frying. Braz. J. Chem. Eng. 22, 271-276.

Sosa-Morales, M.E., Espiritu, R.O., Velez-Ruiz, J.F., 2006. Mass, thermal and quality aspects of deep-fat frying of pork meat. J. Food Eng. 77, 731-738.

Tchobanoglous, G., Burton, F.L., Stensel, H.D., 2003. Wastewater Engineering Treatment and Reuse, fourth ed. McGraw-Hill, New York.

Totte, A., Diaz, A., Marouze, C., Raoult-Wack, A.L., 1996. Deep-fat frying of plantain experimental study of solid liquid phase contacting system. Lebensm. Wiss. Technol. 29, 599-605.

Ufheil, G., Escher, F., 1996. Dynamics of oil uptake during deep-fat frying potato slices. Lebensm. Wiss. Technol. 29, 640-644.

Werther, J., Ogada, T., 1999. Sewage sludge combustion. Prog. Energ. Combust. 25, $55-116$.

Yamsaengsung, R., Moreira, R.G., 2002. Modelling the transport phenomena and structural changes during deep fat frying. Part I: model development. J. Food Eng. 53, 1-10. 